\title{
Independent Woman in Novel Gadis Kretek by Ratih Kumala
}

\author{
Thera Widyastuti ${ }^{1}$ \\ thera.widyastuti@gmail.com ${ }^{1}$ \\ Department of Literature, Universitas Indonesia ${ }^{1}$
}

\begin{abstract}
Society is changing from time to time. Women's roles and positions are changing, especially in the fields of economic and social. Their participation in the public domain has an impact on their families and societies. This research discusses novel Gadis Kretek by Ratih Kumala. Dasiyah is a female character in this novel. She intended to be independent, despite her family owned a kretek cigarette factory. The research problem is how the independence of the female character is narrated, and the research objective is to discern the independence performed by the female character. The method is descriptive-analysis. To analyse the research problem, the research applies are character, sociology of literature, and feminist literary criticism. The kretek cigarette industry in Town of M developed, so did Dasiyah's. She generated ideas to make her kretek cigarette industry advanced; thus, it signified her as an independent woman.
\end{abstract}

Keywords: independent, industry, kretek cigarette, woman

\section{Introduction}

A work of literature is a writer's creative process towards a reality that exists in a society. It is a mirror of social lives. A good work of literature contains an ultimate truth for human beings as long as they still exist [1]. The connection between a writer and a society is very close considering that the writer is a part of the society in which he or she lives.

God created human beings, men and women, to live on earth. They have their own ways to communicate many things, such as problem-solving, emotions, and decision-making. However, women are deemed as weak creatures and must be protected.

Women and their problems become one of interesting issues for female writers. One of them is Ratih Kumala, an Indonesian writer. Her novel Gadis Kretek, which was published in 2012. Some of her works attained awards, Tabula Rasa attained $3^{\text {rd }}$ position in the Jakarta Art Council Novel Writing Contest in 2004, Gadis Kretek was listed in the Shortlist of Khatulistiwa Literary Awards in 2012, and Bastian dan Jamur Ajaib was listed in the Longlist of Khatulistiwa Literary Awards in 2015.

This research discusses novel Gadis Kretek, which narrates a female character named Dasiyah, whose family owned a kretek - or clove - cigarette factory in Town of M. She works in a place dominated by men. This male dominance caused women to strive to equalize their position in this industry. Dasiyah's independence made her to be able to produce brilliant ideas and thoughts, and to create a new breakthrough in the kretek cigarette industry in Town of $\mathrm{M}$.

The research problem is how the independence of the female character in novel Gadis Kretek is narrated. Whilst the research objective is to discern the independence that is performed by the female character. 


\section{Literature review}

Researches concerning women and their independence are not new. Some of the researches that relate to independent women are: (1) Perempuan dan Kretek dalam Novel Gadis Kretek Karya Ratih Kumala. Diah Ajeng Lestari. 2016. Universitas Airlangga. Her research indicates that a woman was a human being who had freedom to behave, and being a woman could do things that related to men's world, that is, the world of kretek cigarettes. Therefore, men and women possessed the same influence and rights, (2) Citra Perempuan Mandiri dalam Novel Athirah Karya Alberthiene Endah. Mien Dwi Pratiwi. 2018. Universitas Muhammadiyah Malang. This research concludes that the main character, Emma Athirah, was able to be independent by overcoming problems encountered in her social life.

\section{Method}

The method that will be applied in this research is descriptive-analysis. The descriptive analysis method as a method that serves to describe an overview of the object under study through data or samples that have been collected as they are, without analysing, and making conclusions that are applicable to the public [2].

This research applies two approaches: the intrinsic approach to examine the literary feature (character, and setting), and the extrinsic approach to examine the external aspects (the sociology of literature and feminist literary criticism). The data collection method is a literature study with novel Gadis Kretek as the main data.

\section{Theoretical framework}

Three theories used in this research: character, sociology of literature, and feminist literary criticism. A character is an important element in a literary text; thus, based on the roles and the level of importance, there are major character and minor character [3].

An approach towards the literature that considers its social aspects is sociology of literature. By using text analysis to identify its structure, it is applied to comprehend more deeply about social indication outside the literary [4].

Gender is an activity role and an achievement, which is obtained through an interaction in a social situation. Sex and gender have a different meaning. Both are a conception that must be comprehended. Sex refers to the difference of genitals between men and women. Whilst gender is a social construction in a cultural that distinguishes sexes. The background of gender issue is initiated by a universal perception that culture tries to rule, and manage the nature for human beings' requirements. In this context, men are symbolized as culture, and women as nature, who are ruled and managed by men.

The feminist literary criticism is not a critique towards literary criticism; rather, it is a perception that refers to various ways in the discussion of the social difference concept [5]. One of the feminist literary criticism variety is feminist literary study, which one of its focuses is studying works of literature through a feminist approach. The feminist approach is a work of literature approach by focusing on the inequality gender relations, and promoting on the equal level between men and women [6]. 


\section{Result and discussion}

Novel Gadis Kretek narrates the life of a society in Town of M, whose inhabitants mostly worked in cigarette factories. Many cigarette factories there and, thus, the competition among them was tight.

In a novel, there are characters who become a part in the element of the story. Characters are those who bear events in the fictional story so that those events intertwine it. The way that the writer portrays those character is called characterization [7].

A major character can be observed from his or her high intensity of appearance in a story, frequently involvement with other characters, appearance as the centre of a story, or name taken to be the title of a novel [8]. Accordingly, the major character in novel Gadis Kretek is Dasiyah, Her father, Idroes Moeria, was a kretek cigarette businessman and her mother, Roemaisa, was a clerk's daughter. She was a beautiful young woman and a friendly person.

Who did not know Dasiyah, the flower of Town of $M$, a kretek cigarette businessman's daughter who was beautiful? She was a cheerful girl who always friendly to any one whom she came across. Her smile never disappeared from her pretty face, as if that smile was deliberately was put on as a jewellery, like a necklace or earrings ( $p .176)$.

Dasiyah grew as a deft and smart girl. She was able to compete with boys; thus, her father was contented. Her father's concern about not having a son was disappeared. Idroes Moeria was really proud of her.

Idroes Moeria was no longer worried when his wife, Roemaisa, did not gave birth to a son. He was contented to have Dasiyah; that girl, even though was not completely a tomboy, possessed an energy like a son in a family who took the responsibility. Her daughter, also, was deemed to possess an instinct and good wisdom if related to their kretek cigarette business (p. 176).

A daughter frequently is portray as a weak and powerless figure. As a result, parents wish for a son more than a daughter. The presence of a daughter that can make her parents proud is something special.

The minor character in the novel is Idroes Moeria, a man who came from a poor family. Since little, he lived with his mother after his father passed away. He had a goal to escape from poverty so that he could prosper his family, and make his mother happy. To fulfil the goal, he had to work hard.

Idroes Moeria only lived with her mother. That young man knew, he would become the backbone of the family after his father passed away when he was 13 years old, even though her mother also worked as a housemaid in their neighbour's house, who was far more settled (p. 49).

Idroes Moeria, like most other young men, had a goal for a better future. He knew that he must cut the family poverty line so that his children and grandchildren prosperous. He wanted to make his little family happy and - of course - his mother (p. 50).

In the beginning, he was illiterate because he never attended school. The poverty made him unable to attend school. His mother, who worked as a housemaid, did not have much money to school him. 
That made Idroes Moeria felt inferior, considering that he only could read Arabic alphabet. That, too, he could not understand the meaning, like other children. All of the children learnt to recite The Qur'an in the mosque; so, all of them could read Arabic alphabet, other alphabets could not, unless they attended school (p. 52).

Eventually, Idroes Moeria decided to enrol to a local school. He was determined to learn how to read; although it meant that he had to be absent from work for a few days at the risk of not having money (p. 57).

Initially, he only could read in Arabic alphabet. However, he was determined to learn how to read Latin alphabet so that he could read and write. He believed that education could change his life better. Finally, he could read, write, and count. Since then, his life became better, and succeeded to become a kretek cigarette businessman in Town of M.

The day, suddenly, became so cheerful for Idroes Moeria. He could see his future with children who encircled him, at a decent home, which he built from his sweat and money. He was, too, sure that he could look after her mother, who was so old, well until her last breath; also, his in-law (p. 99).

The character of Dasiyah, also called Jeng Yah - means Sister Yah, is described by the writer as a smart woman. She possessed a bright idea about the establishment of a kretek cigarette factory. Her independence can be observed from her intention to run the business. She envisaged that there was an opportunity to advance. She intended to create her own kretek cigarette brand, Gadis, even though her father owned several brands, which one of them was Merdeka!.

Independence is someone's condition that is able to take the initiative, is able to overcome a problem, possesses sense of confidence, and can do anything by him- or herself without depending on other people [9].

For Jeng Yah, her life had been complete. She possessed Gadis brand that was so advanced. Merdeka! brand, too, still continued to produce with its distinctive red coloured cigarette paper ( $p$. 201).

Dasiyah knew the kretek cigarette business for the first time when she was 10 years old. It was when she earned her first wage as a hand-rolled worker in her father's factory. Therefore, she had been in the public domain from an early age.

When Dasiyah was 10 years old, that petite girl was already skilful at rolling up kretek cigarettes. She used to socialize with hand-rolled workers since little. Since she was able to walk, she made them worried that she would fall down because not balanced yet. Then, she became a vivacious young woman, so was Rukayah, her younger sister. Both of them regularly visited those hand-rolled workers, and played with clove and tobacco. They took the rolling machine and Dasiyah commenced to roll up, whilst Rukayah trimmed the excess tobaccos. They both requested a pay from their father, counted from how many sticks of kretek cigarettes they had produced (p. 127).

Dasiyah's success in running the business of both Gadis and Merdeka! kretek cigarette brands made her confident. Her experience in assisting her father to roll up cigarettes since little had made her skilled it concocting kretek sauce. 
Should, unintentionally, they produced quite many kretek cigarettes that day, their palms would be sticky with extracts of clove until they could be scraped with nails or a spoon. Whereas most of the hand-rolled workers preferred to wash their hands from extracts of clove that stuck on their palms. Dasiyah, on the contrary, preferred to collect them. She knew that her father also did the same whenever, by chance, she partook in rolling up with him. Then, the ritual was commenced. The ritual that, in the future, would take Dasiyah to become a clove cigarette girl (p. 127-128).

Dasiyah habitually observed her father's ritual. Subsequently, she collected the extracts of clove in the late afternoon. Willingly, she even requested Rukayah too to collect them that stuck on her palms. She handed over all of them to her father ( $p .130$ ).

That late afternoon, she partook in cutting the extracts of clove that already in the form of sheets. Then, she tried to mimic her father rolling up, even licking the edge of the cigarette papers so that they were sticky (p. 131).

"The filling should be much more, so that the cigarettes are quite thick. These ones too thin, their sizes are different compared to those for sale," said Dasiyah, whilst handed over the cigarettes, which she had rolled up. Even though it was the first time to roll up without a rolling machine, Dasiyah had done it neatly (p. 131).

She became often to partake in rolling up in the factory because she knew should rolled up more frequent, the more she would obtain the extracts of clove. They could only be obtained should she assiduously assisted her father. Dasiyah was really aware about this matter. She would observe her palms, which initially were clean then changed into brownish, and that brownish tone became thicker (p. 132).

Like what had been done by her father, Dasiyah pressed those extracts of clove, which resembled hardened paste, under a hot teapot until flat. Afterwards, she cut them into small pieces. Thoroughly, she commenced to roll up one by one. The sticks of cigarette that were deliberately rolled up neatly. She produced twenty sticks that contained a blend of extracts of clove (p. 134).

Dasiyah ran her own business; hence, a businesswoman. A businesswoman is a woman who does business (trade, industry, and so forth); also, it can be said as a woman who struggles in trading [10]. The businesswoman's objective is to assist in the economic problem and to sustain and increase the family's economic growth rate. In the system of socio-culture enables women in a subordinate position, in spite of having a double role [11]. This situation was not experienced by Dasiyah because she was a superordinate.

Dasiyah's intelligence made her to be able to do analysis, and a brilliant business consideration. She did not hesitate to make a firm decision so that her factory could continue to produce.

"If you, Father, build a new brand again, it means that you take the capital of Merdeka!. If failed, it means Merdeka! will not be able to be in production any longer. What will we eat? Our workers will be paid with what?" Stated Dasiyah firmly. "If you can find an investor, go ahead then. But, for sure, do not spoil the capital of Merdeka!" (p. 140-141).

Her intelligence inherited from her mother, Roemaisa. The way she talked and behaved reflecting her intelligence. Her father was aware that her daughter could be his successor. She was able to work hard, and be a wise leader. 
That girl inherited the intelligence from her mother, and the working tenacity from his father. Moreover, due to Idroes Moeria's stance, which tended to give freedom for his daughter, she became an independent woman, dared to express an opinion. A unique combination for a woman in that time (p. 140).

Even, that time, Idroes Moeria was stunned. He just realized her daughter like a flower. He was like seeing Roemaisa in the day he was about to propose her, came out from behind the curtain like a flower uncovered from bushes. It just only this time Dasiyah's gesture was different from that of young Roemaisa. Dasiyah appeared with a smile, and not afraid to stare at her interlocutor's eyes, her face kept all of knowledge, everyone knew she was a smart woman. She charmed the entire room with a different way yet induced the same awe (p. 142).

Dasiyah's marketing skill was extraordinary. She possessed brilliant ideas to market Gadis. She did not hesitate to spend money to make the brand more popular. The night market became one of places to market the brand.

Since Town of $M$ was a small town, at best the night market was held once a year. Usually near $17^{\text {th }}$ August. When the time came, undoubtedly Dasiyah registered Gadis as one of the stands there. She became so popular among the night market people. Everyone knew if there was the only one woman who managed a kretek cigarette stand seriously, it was Dasiyah, or Jeng Yah, as they called her ( $p$. 153-154).

Someone's role in a society is inseparable from the rights and obligations. The role involves at least three matters: a) a role that comprises norms associated with a position or someone's place in a society; b) a role that is a conception concerning what an individual can do in a society as an organism; and c) a role that also can be stated as an important individual's behaviour for a social structure [12]. Therefore, Dasiyah's role was the role that comprises of norms associated with a position or someone's place in a society.

The division of work carried out by Dasiyah generated a great impact on Gadis business. She employed not only men in her factory, but also women, and they all were paid the same amount.

The sales figures of Gadis skyrocketed, along with Dasiyah who enthusiastically registered it to participate in night markets, which were held at certain times. Not only was held in Town of $M$, but also in Yogyakarta, Magelang, Solo, Kudus, and the farthest in Lampung. Letters from Banyuwangi and Kalimantan also came, from those who heard that Gadis was a best-selling kretek cigarette brand. They deliberately proposed themselves to be the distributors in their respective areas ( $p$. 153).

The division of work that based on sex difference is arranged by the nature to create a life of civilized society. It has been happening for thousands of years. Therefore, people inclined to deem it as something natural. They inclined to not questioning whether it is fair and who benefits from it. Women deem that the role difference, which is given to men and women, has an equal value: both are a noble role and worth to defend [13]. This situation is portrayed in Dasiyah's idea that employed young women in the marketing of Gadis.

Afterwards, Dasiyah had an idea, instead of employing male stand guides, she employed Rukayah's female friends. She paid them the same amount as male stand guides to promote Gadis (p. 153).

Female workers in Gadis factory received the same amount of wages as male workers. Wages for workers were an essential factor because they were the source to finance 
themselves and their families. Wages are everything that workers, employees, or labourers receive as a compensation for work done [14]. As the leader, Dasiyah made a crucial decision by equalizing the wages for her male and female workers. The Marxist-feminist thinkers believe that the economic power and position that good for women are the answer to bring to an end the oppression towards women [15]. Moreover, they pioneer Comparable Worth movement, which not only to ensure a better wage for women, but also to compel the society to reconsider why they pay some people with high wages, and the others with low wages [16].

Dasiyah learnt to run kretek cigarette business, and the way to make kretek cigarette sauce. Her experience since little made her mastering in how to concoct a flavourful sauce. She knew the intricacy of kretek cigarette production; thus, it was not surprising that her kretek cigarettes, which she rolled up by herself, so flavourful.

In reality, it was Dasiyah who really tasted those kretek cigarettes, especially in the late afternoon when the tea time. This made her tongue and sense of smell were trained to distinguish the flavour of a stick of kretek cigarette whether good or not good. According to her (which certainly was kept for her own), those kretek cigarettes were not better than Merdeka!. Personally, Dasiyah preferred Merdeka! (p. 139).

Since little, every late afternoon, Dasiyah rolled up cigarettes and then handed over her father. Because of that, she knew what the flavourful sauce should be. She intended to create a special sauce for her Gadis. Her skill in concocting flavourful sauce that made brand favoured by many people.

Actually, Dasiyah secretively had blended various sauce ingredients by herself. She took the sauce of Merdeka! as the base, and added some ingredients, which she assumed, could make the flavour more perfect (p. 150).

Most of Indonesian people had a penchant for smoking. For them, smoking would be more complete should it was accompanied with drinks. Coffee or tea was chosen to be a loyal companion.

Tea and coffee definitely were loyal companions combined with kretek cigarettes. However, to decide the right partner, either tea or coffee to be sipped, one had to look at the sun. Should the sun in the east sky, coffee was more appropriate to be partnered with kretek cigarettes. On the contrary, should in the west sky, it was tea (p. 128).

They deemed that the smoking activity accompanied by coffee or tea could raise the sense of enjoyment whenever the cigarettes were inhaled. Either coffee or tea, they consumed it alternately.

The existence of kretek cigarettes were favoured by most of people. For that reason, the development of the kretek cigarette industry provided such impacts on the people's lives. Many of them depend their lives on the kretek cigarette factories. A good marketing and a flavourful concoction made people to favour kretek cigarettes. 


\section{Conclusion}

Novel Gadis Kretek by Ratih Kumala narrates Dasiyah's life, an independent woman in her struggle to build a kretek cigarette brand, and its factory in Town of M. She grew as a woman who was skilful at concocting kretek sauce, as a result of her experience rolling up kretek cigarettes in her father's factory.

Since she had been in the public domain, she became confident that she was indeed mastering the technique of making kretek cigarettes. In fact, the kretek cigarettes made by her have a flavourful kretek sauce. Therefore, she intended to establish her own business in the kretek cigarette industry.

Dasiyah's independence is discerned through her firmness in making decision, and her ideas that made her Gadis kretek cigarette brand advanced and developed rapidly. She expanded her business through an innovative marketing strategy. She became the head of the kretek cigarette factory; thus, superordinate. Moreover, she employed female workers and paid them the same amount of wage as male workers.

\section{References}

[1] Sumardjo, Jakob dan K.M. Saini. Apresiasi Kesusastraan. Jakarta: Gramedia Pustaka Utama, 1991.

[2] Sugiyono. Metode Penelitian Kuantitatif, Kualitatif, dan R\&D. Bandung: Alfabeta, 2009

[3] Nurgiyantoro, Burhan. Teori Pengkajian Fiksi. Yogyakarta : Gadjah Mada University Press, 2002.

[4] Damono, Sapardi Djoko. Sosiologi Sastra: Pengantar Ringkas. Ciputat: Editum, 2009.

[5] Sugihastuti dan Suharto. Kritik Sastra Feminis, Teori dan Aplikasinya. Yogyakarta: Pustaka Pelajar, 2002.

[6] Djajanegara, Soenarjati. Kritik Sastra Feminis: Sebuah Pengantar. Jakarta: Gramedia Pustaka Utama, 2000

[7] Siswanto, Wahyudi. Pengantar Teori Sastra. Jakarta: Grasindo, 2002.

[8] Siswanto, Wahyudi. Pengantar Teori Sastra. Jakarta: Grasindo, 2002.

[9] Syafaruddin. Pendidikan dan Pemberdayaan Masyarakat. Medan: Perdana Publishing, 2012

[10] Hatikah, Tika dkk. Membina Kompetensi Berbahasa dan Bersastra Indonesia. Jakarta: PT. Grafindo Media Pratama, 2006.

[11] Hadiz, Liza. Perempuan dalam Wacana Politik Orde Baru: Pilihan Artikel Prisma. Jakarta : Pustaka LP3IS Indonesia, 2004.

[12] Soekanto, Soerjono. Sosiologi: Suatu Pengantar. Jakarta: Radja Grafindo Persada, 2007.

[13] Budiman, Arif. Pembagian Kerja Secara Seksual. Jakarta : PT. Gramedia, 1985.

[14] Dessler, Gary. Manajemen Personalia. Jakarta : Erlangga, 1997.

[15] Arivia, Gadis. Filsafat Berperspektif Feminis. Jakarta: Yayasan Jurnal Perempuan, 2003.

[16] Tong, Rosemarie Putnam. Feminist Thought. Yogyakarta : Penerbit Jalasutra, 2008 